\title{
The Celebration of Lesbian Female Psyche in Jeanette Winterson's Oranges Are Not the Only Fruit: A Critical Study
}

\author{
${ }^{1}$ Ritushmita Sharma, ${ }^{2}$ Porishmita Buragohain \\ ${ }^{1}$ Research Scholar, Department of English, Dibrugarh University \\ ${ }^{2} \mathrm{Ph} . \mathrm{D}$ Research Scholar, Department of English, Dibrugarh University
}

\begin{abstract}
Jeanette Winterson's Oranges Are Not the Only Fruit (1985) taps into the increasing popular interest for exploring the ways in which gender and sexual identities are constructed in the mainstream British culture. Often been considered an autobiographical and a bildungsroman, this book has successfully dealt with the protagonist's self-development from infancy to adulthood and her search for individuality through a series of formative experiences. These experiences, however, encapsulates her struggle againstthe oppression of religion of the asphyxiating society where she lives, in her sexual initiation, in her subsequent isolation, and finally in her success to move away from oppression to freedom and independence. Thus this research paper is an attempt to excavate how Winterson has challenged the prescribed set of attitudes of a society (especially the religious ones) towards sexuality through the experiences of a character who experiences her lesbian identity within a closed society that rejects same-sex love and tendencies. Moreover, this paper also aims to redirect our focus towards the breaking down of traditional clear-cut boundaries with respect to the artificial construction of gender and identity.
\end{abstract}

Key words: gender, religion, lesbian, British culture

\section{Introduction:}

A cursory glance at the theoretical underpinnings of the studies on Gender and Sexuality would unveil that although human beings are classified into the categories of male or female, the ideas related to their identification as masculine or feminine is not predetermined but socially formulated. This same notion has been expressed in the monumental work titled as The Second Sex (1949) by the second wave feminist Simon de Beauvoir who sums up her central argument as "one is not born, but rather becomes, a woman". Falling back on Beauvoir's ideas, one may claim that the ideas related to one's femininity or masculinity are nothing but the artificial constructs of a society whose power relations are produced and reproduced by the dominant patriarchal relations or by those who wishes to retains onto power. It is therefore quintessential to examine different societal codes which demarcated the role of women via subjugation, stereotypical representation and their different forms of struggle and resistance that they set forth to answer for their marginalisation. A strong influence of Feminism is pertinent in the works of fiction by British writers as they dealt extensively with feminist issues that began to be surfaced in the late 1960s and 1970s. These writers include the names of eminent writers like A. S. Byatt, Angela Carter, Margaret Drabble, Fay Weldon etc.

After a remarkable success of the credos of Feminism in between the years 1970 to 1980 , a drastic change is displayed not only in the socially accepted roles of women but in men too. This lead to the reevaluation of gender role with respect to men and masculinity as socially constructed, like that of women. As put forwarded by Betty Friedan in her The Feminine Mystique that "Men weren't really the enemy-they were fellow victims suffering from an outmoded masculine mystique" (57), it implies the beginning of the concept called 'the New Man' which implies the category of men (especially the heterosexuals) who support the cause of equal rights between men and 
women. This as a result brings into focus many of the major male writers who started surveying in their works different frameworks of gender and newer approaches of masculinity. In this context, one may refer to British writers such as Julian Barnes, Martin Amis in the 1980s who significantly has dealt with their interests on ideas within the realm of masculinity studies.

Apart from all this, a revolutionary change in the attitudes towards homosexuals has secured its recognition and space in British fiction in the last quarter of the twentieth century. To cite as an example, we may refer to the ways in which Gay Liberation Movement in the societies of Western countries have emerged simultaneously with that of the interests and agendas of Women's Liberation Movement. Specifically in the context of British societies, homosexuality has been decriminalised thereby consulting adults who are above twenty-one years of age. But despite all these, homosexual identities are often gazed as criminals, treated with inequalities and accordingly became subjects of many acts of violence. Nick Bentley in his Contemporary British Fiction speaks about prejudices against the homosexuals in Britain. He says:

One of the major international
events that had influence in
Britain was the riot at the
Stonewall Inn, a lesbian and gay
club in New York City, in May
1969. The riot was a response to
the unjustified but repeated raids
on the bar made by police during
this period. The events served to
bring to popular attention the
injustices carried out against the gay and lesbian community

generally ... (15)

This in turn has necessitated the formation of LGBTQ movement and paved the ways for 'Queer Theory' which focuses all its attention to disrupt the patterns in which one's sexuality or gender are conceived in a society. Queer theory aims to offer an overall analysis of both lesbian and gay studies which comprises of all the critical explorations of ideas such as bisexuality, transsexuality, homosexuality which are not at all considered to be normal in a society that coheres to the heterosexual norms. M.H. Abrams in his the glossary of Literary Terms defines the term 'queer' which was originally used in a derogatory sense, "used to stigmatize male and female same sex love as deviant and unnatural" (253).But since the early 1990s, the gays and the lesbians themselves have begun to accept the ideas related to 'queer' as not an invidious term but as a way of life. This exploration of queer studies has been developed in the fictional works of British novelists such as Sarah waters, Hanif Kureishi, Jeanette Winterson etc. which has lead to the increasing acceptance and recognition of gay and lesbian rights. However, this present analysis aims to concentrate its focus on Jeanette Winterson's novel Oranges Are Not the Only Fruit which appeared at a time when rightwing intellectuals were blaming the left-wing radicals and the 1960s sexual protest for the disruption of family values in the contemporary British societies. Winterson explicitly points out the political debates of the time when she produced this novel. Her statement that Oranges as a threatening novel "exposes the sanctity of family life as something of a sham; it illustrates by example that what the church calls love is actually psychosis and it dares to suggest that what makes life difficult for homosexuals is not their perversity but other people's" (xii) and accordingly openly questions 
the prescribed set of ways in which gender (emphasis added) is constructed. Again to quote Winterson, she extensively speaks about the stylistic nature and structure of the novel. She says:

\begin{abstract}
Oranges is an experimental novel: its interests are anti linear. It offers a complicated narrative structure disguised as a simple one, it employs a very large vocabulary and a beguilingly straight-forward syntax. This means that you can read in spirals. As a shape, the spiral is fluid and allows infinite movement ... I really don't see the point of reading in straight lines. We don't think like that and we don't live like that. (xiii)
\end{abstract}

It is clear from Winterson's argument that she locates her novel in the framework of postmodern narrativisation which is also reflective of her critical engagement with the experimentation of paradoxical elements in language, deconstruction of gender as social construct, along with representation of the self as fragmented and ex-centric.

The novel Oranges Are Not the Only Fruit begins with protagonist Jeanette's (whose name is also same as the author's) growing up in a hostile environment and her journey from childhood immaturity to that of her self-identification. This is a metaphorical journey which is significant in constituting the formative years of her life, followed by her complete rejection of the solidified codes of her society. It is via the protagonist, the novelist challenges the traditional family structure in different ways. Firstly, we may refer to Jeanette's parents who are completely different from each other in the traditional hierarchy between men and women. For example, it was Jeanette's mother who is seen in a role of a dominant and the father, a poor figure. It is also well-informed by the protagonist narrator that her parents lack the evidence of any sexual relationship with one another as she says: "As long as I have known them, my mother has gone to bed at four, and my father has got up at five" (Winterson 15). This can be traced back to another clue about the sexual orientation of Jeanette's mother when Jeanette was going through her mother's photograph album called 'Old Flames'. In it, she encounters photographs of men like Eddy, Pierre, Percy etc. with whom Jeanette's mother was at one point of time sexually involved confusing herself to be in love but in reality she was not. Again while interrogating about another picture of a pretty woman from the 'Old Flames' section, Jeanette's mother removes the photograph which is indicative of her repressed desires. It has been confirmed by Mrs. Jewsbury who herself a lesbian who tells Jeanette about her mother's uncomfortable desires. She says that Jeanette's mother is "a woman of the world ... She knows about feelings, especially women's feelings" (Winterson 110).

Alongside her family, Jeanette since her childhood has been taught by her mother to identify with another social unit i.e., the church group with which she possess cordial relationship. So the experiences she receives from her rigid familial life as well as from the strict parameters of the community church group moulds her perception in a way that she questions the gender codes around her and also the traditional roles of male/female, masculinity/femininity etc. Jeanette's not conforming to the societal attributes of femininity is reflected in her from an early age. For example, one may refer to the time when she reacted 
with rage when the man who ran the Post office gave her 'Sweet hearts'. She says:

\begin{abstract}
Sweet I was not. But I was a little girl, ergo, I was sweet, and here were the sweets to prove it. I looked in the bag. Yellow and pink and sky blue and orange, and all of them heart shaped and all of them said things like,
\end{abstract}

\section{Maureen 4 Ken}

Jack and Jil,True

On the way home I crunched at the Maureen 4 Ken's.

(Winterson 72)

This above instance representing Jeanette's crushing down the sweets offered by a man can be read as her refusal to cohere with the heterosexual norms of the society. In addition to this, hints about Jeanette's sexual orientation are also unfolded when she encounters an old lady who by looking into her palm says that "You'll never marry . . . not you, you'll never be still" (Winterson 6). The old woman's statement immediately strikes Jeanette about the two women in her neighborhood "who didn't have husbands at all", she has been told that "they dealt in unnatural passions" (Winterson 6). So all these images seem to haunt Jeanette when resurfaced in the forms of nightmare and dreams about marriage:

It was Spring . . . and I was about to be married. My dress was pure white and I had a golden crown. As I walked up the aisle the crown got heavier and the dress more and more difficult to walk in...

Somehow I made it to the altar. The priest was very fat and kept getting fatter, like bubble gum you blow. Finally we came to the moment, 'You may kiss the bride.' My new husband turned to me, and here were a number of possibilities. Sometimes he was blind, sometimes a pig, sometimes my mother, sometimes the man from the post office, and once, just a suit of clothes with nothing inside.

(Winterson 71)

It has been suggested here that Jeanette fails to imagine herself married to someone who belongs to opposite sex. This she realises from the time when she begins to perceive things not from someone else's perspective rather out of her own accord. Jeanette's dream here suggests her disgust about the term marriage and at the same time her uncertainty about men. In the dream, she also sees a woman who tells her that all men are piggreedy, slovenly, gruesome - and all these connotations takes root in Jeanette's mind deeply. Thus, she fears that she too will end up marrying a pig, and fears becoming blind and gullible like the women all around her. Jeanette for the first time feels curious and wishes to unravel what it means to be in a relationship with man. She therefore goes to the library and reads a story called "Beauty and the Beast" which makes her wonder that what would women do when they find that they have married a beast-many beasts in stories disguise themselves, and perhaps, she thinks, women all over the world are marrying beasts "in innocence" (Winterson 73). Thus Jeanette from this story draws one conclusion that "I had stumbled on a terrible conspiracy" (Winterson 73). Here by the term 'conspiracy' refer to the politics of a heterosexual society which assumes that sexual and marital relations are the most fitting between 
the people of opposite sex. This 'conspiracy' Jeanette wishes to escape and therefore when she overhears the conversation about a neighbor's daughter's "unnatural passions", the nuances of which she was quite young to understand, but she understands in a distant manner that perhaps marrying a man is not the only option. This eventually prompts her to realise that heterosexuality is not the only norm.

Jeanette's rite of passage from childhood to maturity is also built upon her reading of another novel i.e., Charlotte Bronte's Jane Eyre. Bronte's novel serves as one of the significant intertext in Winterson's Oranges Are Not the Only Fruit as in both these two novels, the protagonists Jane and Jeanette are placed within a harsh environment. It has been pointed out that Jane Eye is Jeanette's mother's most favourite nonBible book which she read it to Jeanette over and over again from the time when she was very small. However, her mother presented a bowdlerized account of Jane Eyre's ending wherein Jane marries religious St. John Rivers but not passionate Mr. Rochester. But later on when Jeanette decides to read the book for herself, she discovers that Jane in actual does not marry St. John Rivers at all, but she goes back to Mr. Rochester. This makes Jeanette realise that all her life her mother tried to impose the ways she led by her own. Jeanette's mother's interpretation of Jane Eyre is very much related to her own life as she chooses to marry who is safe and silent. Similarly, Jeanette's mother wishes the same for her own daughter to marry safe and silent and at the same time wishes to control her unrepressed desires as she constantly says "Yield Not to Temptation" , which according to the novel, is the lesbian desire.

The disclosure of lesbian desire in Jeanette who finds love with the same-sex initiated within her a sense of alienation from her family, friends and society- firstly from her mother whose radical views about religion creates within Jeanette a sense of conflict; and secondly, the religious excess which is creeped into the lives of the community people as a threat rather than any comfort. The tormenting effect of extreme religiosity is reflected in the scene when Pastor Finch "an expert in demons" who delivered "a terrifying sermon on how easy it is to become demon possessed" (Winterson 11). Jeanette feels threatened more when the Pastor says that although evil may possess anyone, yet the weaknesses of women and children make them more prone to be possessed and in such an authoritarian set-up, she begins to feel more at loss in her mother's betrayal by agreeing with the Pastor who reimposes the patriarchal narrative into Jeanette's behaviour. Jeanette says:

It all seemed to hinge around the fact that I loved the wrong set of people. Right sort of people in every respect except this one; romantic love for another woman was a $\sin . .$.

As far as I was concerned men were something you had around the place... I had never shown the slightest feeling for them, and apart from my never wearing a skirt, saw nothing else in common between us. Then I remembered the famous incident of the man who'd come to our church with his boyfriend. At least, they were holding hands. 'Should have been a woman that one' my mother remarked. (Winterson 128-129) 
Jeanette till this point of her life realises that for the society, her sexual orientation is a 'fall' from the natural law, and subsequently this leads her to seclusion without any food or drink so that so can she lose her strength and be exorcised. But Jeanette's impossibility to rebel against her own sexuality leads her to start new relationship with Katy later on.

Jeanette also feels betrayed by her mother which serves as a major turning point in her life. Jeanette has forever idealized her mother for her strong female image but now prepares her own ways to assert her identity and individuality. Jeanette says:

There are different sorts of treachery, but betrayal is betrayal wherever you find it . . . In her head she was still queen, but not my queen any more, not the White Queen any more. Walls protect and walls limit. It is in the nature of walls that they should fall. (Winterson 110)

Moreover, Jeanette's sense of lesbian desire and giving recognition to her feelings for Melanie shows her absolute conviction that there is nothing wrong or 'unnatural' about her behaviour.But the homophobic society around Jeanette and Melanie accuses them to have fallen under the spell of Satan and therefore began to be treated as perverse children full of demons. Jeanette in this context says:

I knew that demons entered wherever there was a weak point. If I had a demon my weak point was Melanie, but she was beautiful and good and had loved me.
Can love really belong to the demon?

What sort of demon? ...

'They're looking in the wrong place,' I thought. (Winterson 108-109)

The aforementioned instance can be perceived as a disruption of patriarchal social order and at the same time also serves as a challenge against homophobia or homophobic society. Jeanette's sexual identification with Melanie therefore sets out to question the traditional discourses related to gender and sexuality. Jeanette also questions the religion of which she was once an ardent follower in a society which upholds and privileges only heterosexual nuclear family as the ideal social unit.

From the reading of this novel, one may understand that the novelist has designed each of the chapters on the first eight chapters of the Bible. For example, first chapter titled 'Genesis' recounts Jeanette's earliest memories, her relationship with her parents, and the details about how her mother has got Jeanette (Winterson 9). Again, the second chapter 'Exodus' delineates Jeanette's journey from her home to school and so on. It is only in the last three chapters of this novel, 'Joshua', 'Judges' and 'Ruth', Jeanette seems to establish for herself an alternative world view for herself. It is noteworthy here to mention that the names of the book chapters in this novel correlates to the books in the Old Testament where there are stories about human subject position who either conforms to or rejects against the word of God. However, the last three chapters of Oranges Are Not the Only Fruit, quite unlike the books of the Old Testament seems to support Jeanette's attempt at flouting religious orthodoxy and 
her attempt at fleeing from the shackles of patriarchal structure of marriage and society that privileges heteronormative codes. So it can be said that the Old Testament (which is symbolic of patriarchal God to which her mother and the community member blindly conceded) is replaced by an alternative discourse which is more or less similar to the ideas of New Testament that celebrates the virtues of love over obedience, tolerance and forgiveness over discipline and punishment. Jeanette's love for Melanie she considers it to be taken from the New Testament, as she cites from St. Paul "To the pure all things are pure" (Winterson 103). Thus, in this context, Jeanette's discovery of her lesbianism must not only be understood as her sexual choice but also as an ideological position which posits women-to-women (as proposed by Adrienne Rich) as an alternative design to male/female binary.

\section{Conclusion:}

Thus, the novel offers an alternative to the traditional representation of the lesbians, a tradition which cast the lesbians as 'deviant'. In this way, the novel demonstrates that gender is not a fixed category but a social construction and reveals that it is the intolerant and one-sided approaches to life as performed in educational institutions, religious institutions, and household or by extension the community which forms the basis of oppression. Winterson employs an exclusively female voice oriented towards the exploration of the coming-out process of a lesbian consciousness and in this process provides critique against the wrongs of heterosexual prejudices against homosexuality. So it can be concluded that as both social roles and sexual identity are constructed ideas produced by patriarchy so as to retain the idea of 'heterosexuality' as the normal code of conduct. Moreover, Jeanette deconstructs these ideas by celebrating her female self and by normalizing what society considers as 'unnatural passions'. Thus, Winterson's Oranges Are Not the Only Fruit completely denounces the idea of homophobia and concentrates its complete focus upon the normalization of the lesbian experience challenging the values and assumptions of gender and sexuality.

\section{Works Cited:}

1. Griffin Gabrielle (1994), It's My Party: Reading Twentieth-Century Women's Writing, Pluto Publications, London.

2. Humm Maggie (1986), Feminist Criticism: Women as Contemporary Critics, The Harvester Press, Brighton.

3. Onega Susana (2006),Jeanette Winterson, Manchester University Press, Manchester.

4. Weldon Fay (1978), Praxis, Summit Books, New York.

5. --- (1992), Life Force, Penguin Books, New York.

6. Winterson Jeanette (1985), Oranges Are Not the Only Fruit, Grove Press, New York. 